\title{
Policies for the Circular Economy: the Case of Paper Industry*
}

\author{
Paolo Rizzi**, Sandro Danesi ${ }^{* * *}$
}

\begin{abstract}
The circular economy is considered by international institutions such as the United Nations and the European Union as the most urgent strategy to orient the economic development model towards sustainability. To find concrete applications, the circular economy requires greater awareness in consumers and businesses

The Italian paper industry, which boasts high levels of competitiveness at an international level, has initiated important restructuring and rationalization processes over the last decade with a view to recycling and sustainability. Only the final phase of the production process is yet to comply with all circular economy criteria, that is, the recovery of production waste (pulper). Hence, the actual technological and strategic challenge of the paper industry is to phase out landfilling of recyclable waste and implement energy recovery strategies, as well as promoting the use of renewable sources.
\end{abstract}

Keywords: Circular Economy; Industrial Processes; Paper industry; Sustainability; Global Competition

\section{The Circular Economy and the Paper Industry}

Energy prices and the costs of several raw materials are forcing industries to rethink their production processes and subsequently, their business models. This offers the opportunity to create a new plan for investment projects that can be potentially profitable for the economy, employment and the environment.

Such scenario poses stimulating challenges for entrepreneurs who have the chance to unlock their intuitions, skills and sensitivity towards the environment and its inhabitants while delineating concrete actions and anticipating upcoming economic development. All this can be achieved through new business models for innovative industrial processes that can prove crucial in accelerating the transition towards a circular economy.

\footnotetext{
* The Authors: Rizzi, P. $\S ~ 1,2$, Danesi, S. $\S \S 3,4$

** Associate Professor of Political Economy, Università Cattolica del Sacro Cuore (paolo.rizzi@ unicatt.it)

*** Policy Advisor and Business Consultant, Local Economy Laboratory, Università Cattolica del Sacro Cuore (info@sandrodanesi.com)
}

Edited by: Niccolò Cusano University

ISSN: 1593-0319

Rizzi P. \& Danesi S. (2021). Policies for the Circular Economy: the Case of Paper Industry. Symphonya. Emerging Issues in Management (symphonya.unicusano.it), (1), 76-84.

https://dx.doi.org/10.4468/2021.1.08rizzi.danesi 
The paper industry at worldwide level is initiating such process in anticipation of the expected outcome of new business models that are currently being planned. On the one hand, multinational companies contribute eco-friendly production processes focused on recycling waste into a product that can be fed back into the new process, the ultimate result of which will be efficiently disseminated to all the inhabitants of the world. On the other hand, medium and large non-internationalized companies believe that such outcome will constitute a key factor in the much-needed market repositioning, with widespread recognition to innovative production processes and products with an added value shared at the international level.

\section{Policy and Development of the Circular Economy}

New investments aimed towards the rationalization and restructuring of production processes in the pursuit of a circular economy goal follow, on the one hand, the guidelines of international and European economic policies for territorial development, with a focus towards environmental sustainability. On the other hand, these are guided by particularly intuitive, sensitive entrepreneurs and business executives strongly orientated towards environmental protection and quality-of-life improvement (Salvioni \& Almici, 2020).

Strategies capable of combining competitiveness and sustainability, both on a territorial and corporate scale, are indispensable today as they can increase the resilience of regions and productive organizations (Cantoni et al., 2019; Brondoni \& Zaninotto, 2018; Brondoni, 2014; Rizzi, 2018; Rizzi et al., 2015; Graziano et al., 2018; Latini, 2019; Penco et al., 2019).

At the international level, the turning point came with the signing of the 2015 Paris Agreement for Climate Change and the definition of the 2030 Agenda (United Nations 2015). The main objective is to reduce greenhouse gas emission to mitigate the impact on climate changes already underway, as well as the aspiration to reach net zero carbon emissions by 2050. The crisis triggered by the COVID-19 pandemic may become a driver for accelerating transformations in progress as it represents an opportunity to deeply rethink the economy and the environmental system altogether. Recovery strategies should entail sustainable conversion to work steadily towards the ultimate goal of global climate neutrality and green economy investments, which are likely to lead to an overall positive employment impact. The challenge is to promote ecological-oriented innovation across the various economic sectors and enterprises, as well as change the behaviour of individuals, communities and organizations in order to implement a decarbonisation and energy transition process.

The top priorities for the Italian National Strategy for Sustainable Development are choices III "Affirming sustainable models of production and consumption" and IV "Decarbonising the economy", considering the main targets of the 2030 UN Agenda (United Nations 2015). In particular, Goal 7: Access to clean and affordable energy, Goal 12: Responsible consumption and production and Goal 13: Combating climate change and its impacts, The strategic challenge for the next decades will therefore 


\section{be the one outlined in the EU Circular Economy Package} (European Commission 2014, 2018, 2019).

In other words, a greater responsibility to the subjects located at both ends of the supply chain, namely upstream of production processes. With a specific reference to the planning and ecological design, the selection of materials and commercial channels and, when devising an effective PLM management process, the effective reuse or recycling of EOL products (Fitch-Roy et al., 2020; Ghisellini et al., 2016).

In fact, the aim of circular business models entail reusing and extending a product's useful life through different recovery options such as repair, regeneration, upgrade, adaptation and transformation of used goods into new resources by recycling or switching to renewable resources.

Innovation, from an eco-friendly and circular perspective, may also be promoted through various forms of collaboration, e.g. clustering, that tend towards the development of new models at the supply chain level besides fostering the launch of new start-ups whose mission is to support the transition towards a sustainable economic model. At a more widespread level, this calls for the need to encourage enterprises to adopt certified environmental management systems (EMAS), implement environmental product certifications (e.g. Ecolabel) as well as social and environmental responsibility in both enterprises and administrations (Geissdoerfer et al., 2017; Korhonen et al., 2018).

The guidelines set forth by Italian legislation, in particular, art. $28,1^{\text {st }}$ paragraph of the Ministerial Decree of 9 December 2014, are based on environmental-related investment projects specifically targeted at raising the level of environmental protection beyond the thresholds set by current Community legislation, as well as staying ahead of and adjusting to new EU regulations not yet in force. Such projects can be instrumental in strengthening the level of environmental protection to achieve greater energy efficiency, create higher-efficiency cogeneration systems and implement waste recycling and reuse strategies, in particular for special wastes generated from industrial and commercial activities. Such green economy-related projects encompass initiatives to promote environmental sustainability and a circular economy approach through important product/process innovations, in line, as far as possible, with the provisions of the National Industry 4.0 Plan of the Ministry of Economic Development.

$\square$ Italy is one of the leading nations with a priority to promote the transition to a sustainable economic development model starting with appropriate waste disposal strategies. The circular economy in Italy accounts for approximately 88 billion Euros in turnover, 22 billion Euros in added value, and represents $1.5 \%$ of the national added value. Thanks to the uptake of Italy's circular economy route map, jobs directly associated with the circular economy currently employ over 575,000 people.

The economic crisis - now accentuated by the Covid - is not just an economic, political, institutional - and therefore social - crisis, but is mostly an identity and cultural crisis deriving from the lack of clear industrial models for implementing and 
managing economic policy choices on which economic, social and territorial development should be based.

In such circumstance, it is appropriate to point out that over the past centuries and under much worse economic and social conditions compared to today, several farsighted entrepreneurs contributed to improving the quality of life in their own communities through initiatives that can still be regarded as innovative today and from which we can take inspiration for the future. Worthy of note in this respect are the economic, social and cultural initiatives implemented by the Crespis', a family of Italian entrepreneurs from Crespi d'Adda, founders of one the most important cotton mills in Italy $\left(19^{\text {th }}\right.$ and mid $20^{\text {th }}$ century), not to mention the ingenious worker's village recognized as a UNESCO world heritage site at the end of the 1990s.

Over recent years the current institutional system has shown its lack of ability to attract investment and devise policies to foster the implementation of complex industrial projects. This depends, on the one hand, on a blurred distinction between the roles of political, strategic and technical choices and on the other hand, on a lack of clarity as regards appropriate decision-making and governance processes to be implemented at both the local and national level.

Regrettably, we have lost our perception of the uniqueness of Italian economic history - highly problematic but permeated nonetheless with invaluable intellectual and practical resources. In a deeper sense, historical aspects that are vital for human progress are mostly under-appreciated by the entire community, which therefore fails to provide an adequate response to important questions concerning, for example, its origin, current needs or the path to be undertaken for socio-economic and territorial development. As a result, the slowdown in economic growth in the last decade, resulting in stunted growth over the last three years, and in reduced growth today due to the global health emergency, has brought the nation's consciousness to a standstill.

Notable entrepreneurs of the past, renowned for their ability to combine work, economic interest, profit, passion, dialogue, collaboration and respect for both their employees and themselves, are definitely worth mentioning in this regard. To be more specific, the "give and take" principle they embraced became the cornerstone of their concrete economic, social and environmental actions, which ultimately reflected in a circularity of intentions aimed at the well-being of the population, to which we may add the well-being of the environment.

\section{The Case of the Italian Paper Industry}

In such scenario, speaking of Italian industries, which are known to have traditionally embraced a recycling culture, the paper production sector stands out more than others for its salubrious, biodegradable, widely consumed products that turn out to be extremely necessary and actually indispensable in the wake of the current global pandemic.

Paper making, which reportedly began around 1200 AD, entailed recycling discarded clothes even at that time. Moreover, owing to the scarcity of forest resources in Italy where timber is the source material for making paper and paperbased products, the Italian paper industry has become one of the first in the world to base its manufacturing process on the use of paper for recycling, i.e. waste paper. 
The raw material par excellence used in the paper making process is cellulose of vegetable origin, extracted by shredding wood chips cut from the bark of tall trees (cultivated for this purpose) and subsequently treated at high temperature and pressure. During the process, cellulose is mixed with water and blown at high pressure onto a cloth to allow the formation of a wet sheet (the so-called felting process). This then undergoes a drying phase accomplished through a single cylinder or multiple dryers coupled with an aerothermal system to obtain the final paper web, which is then reeled up. The reels, in turn, are sent to industrial converting plants engaged in the manufacture of tissue paper, napkins and other household and sanitary products.

A fundamental phase in paper production involving the use of both cellulose and waste paper is the drying phase where excess water present in the paper sheet is eliminated before achieving the finished product. Optimizing the paper drying process at this stage is crucial; to this end, the use of gas turbines that generate the drying airflow enables to minimize operating costs and pollution generated by the process. Such innovation is applicable to the entire control software system, including the various plant components, auxiliary devices and subsystems. This allows the management of emissions generated from the process in a more effective way and better adapt them to the extractor hood designed to operate at high temperatures, while testing and experimenting, from time to time, new and unconventional solutions.

In light of the above, it can be said that this sector has proven, over recent years, to have undertaken a crucial and complex path towards a circular economy production system. This is also thanks to farsighted entrepreneurs and their close collaborators, steadily focused on research activities aimed at supporting forestry development, innovation of production systems, energy efficiency and paper recycling (i.e. the recovery of paper manufacturing waste), reintroduction of used goods into the production cycle, all this with a focus on moving towards energy self-sufficiency.

The paper manufacturing and processing industry is primarily engaged in the manufacture of paper products for hygienic sanitary use, food and medical packaging, special-purpose paper and paper for the publishing industry (such as books, magazines and newspapers). The paper industry also fulfils the role of "recycler" despite the fact that its shortcomings in the implementation of waste management infrastructure projects have been dragging on for decades.

The health emergency caused by Covid 19 should be seen as an opportunity to address the complicated issue of managing waste and recycling secondary raw materials in a structural manner, also in light of the Decree containing a list of essential business for Italy. This includes the paper industry (Decree of the President of the Council of Ministers of March 22, 2020, as amended by Ministerial Decree of March 25, 2020, Annex 1, Ateco 17). According to the regulation, the paper industry is deemed as essential as are waste collection and transport activities with the exception of related business. In this respect, the collection of paper for recycling is actually considered fundamental at least as much as the businesses listed in the Decree.

Given the above scenario, the creation of favourable conditions for adopting a Circular Economy approach requires active, competitive enterprises with a strong financial and economic position (Brondoni, 2020). 


\section{Circular Economy Applied to the Paper Industry}

The paper industry represents an example of circular economy as it relies on a technology that is capable of combining environmental sustainability, use of renewable raw materials, recycling of EOL products and recovery of industrial waste.

More specifically, the Italian paper industry holds a large market share with a turnover of 24.8 billion Euros (1.4\% of GDP) and shows a positive trade balance of 3.6 billion Euros. The number of industry professionals active in over 18,300 companies amount to 171,800 (Italian Paper and Graphics Federation, 2019), while employment generated by allied industries amounts to 400,000 (Comieco, 2020).

$\square$ In 2018, the paper sector reported a turnover of around 7.7 billion Euros, recording a $4.2 \%$ growth compared to the previous year (due in part to an increase in the cost of cellulose), with an output standing at 9 million tons and a $0.1 \%$ increase (Paper Industry, 2019). Statistical data show a moderate growth in the packaging and special-purpose paper sectors. As regards hygienic and sanitary paper products, the trend remains unchanged, whereas the demand for graphic papers has seen a decline.

Paper is natural material made out of cellulose extracted from wood coming from sustainably managed forests. The cellulose so obtained is analyzed in order to verify sustainability certifications for a large part of imported paper products. The circularity rate, obtained as the ratio between secondary raw materials and the overall material used, is equal to 55\%, showing levels of excellence mostly at the packaging supply chain level, with a recycling rate of about $89 \%$ (Comieco, 2020).

It is interesting to note that the Italian paper industry currently recycles 10 tons of paper per minute: for example, a newspaper is fed back into the production cycle after 7 days on average and a cardboard box within 14 days (Italian Paper and Graphics Federation).

Recycling also considers the end consumer. In this respect, separate waste paper collection proves crucial in obtaining good quality recyclable paper. The collected materials are processed at waste sorting platforms and it is worth noting that proper collection and sorting schemes are critical in meeting the requirements of the UNI EN 643 Standard, more specifically, the European List of Standard Grades of recovered Paper and Board (materials used as raw material for recycling paper and cardboard products.

The procedures for detecting impurities in paper pursuant to the standards set forth in the European regulations are deemed essential to the recycling chain, which tends above all towards quality to enhance recycling performance. When sorting paper and, more importantly, when recycling it at the paper mills, the amounts of waste generated from the process are modest compared to the large quantities of materials involved. However, since this kind of waste cannot be eliminated, it is considered equivalent to municipal waste.

In light of the above, the goal is to be able to recover the so-called "paper mill pulpier" in order to close the production cycle and meet circular economy requirements. Interestingly, other countries recover energy from waste using wasteto-energy plants as an alternative to landfill disposal. Paper mill waste (pulpier), 
which cannot be avoided, is comprised of plastic and other undetectable impurities such as paper residue, wood, glass fragments and similar matter. Unfortunately, Italian industries, which are not able, as of now, to generate energy from waste as in other European countries, fail to "close the loop" in a circular economy perspective. This results in the concrete risk of having to enter into sector agreements to export waste to foreign countries, leading the way to disloyal competition committed by paper mills from other areas, which would therefore be able to cut manufacturing costs by recovering energy from industrial waste of Italian origin. In such a situation, the paper industry, which is particularly energy-intensive compared to other industrial sectors and uses an excellent fuel such as gas, with higher costs depending on the country - compared to those charged by foreign companies, could lose its competitive advantage when it comes to final costs. To this end, research and development projects have been launched recently to determine which conditions and type of machinery could be deemed most appropriate to recover paper mill waste. An effective approach to waste management would enable the production of gas that could be returned into the production cycle through an innovative, highly technological process. The paper industry would then be able to close the circle and finally meet circular economy requirements (Ouadi, 2013; Toczyłowska-Mamińska, 2017), making waste harmless, at the same time to avoid the release of potentially polluting substances into the atmosphere.

$\square$ The separate collection of paper and cardboard reported
significant results; in 2017, around 3.3 million tons of waste
material were collected throughout the Italian municipalities, with
significant improvement margins especially in southern Italy
(Comieco, 2020). However, the Astra research commissioned by
the national consortium Comieco for the recovery and recycling of
cellulose-based packaging also revealed that three out of five
Italians are wary of the usefulness of separate collection: they
believe that even if paper/cardboard is separated properly from
other waste, it is eventually discarded altogether instead of being
recycled.

Paper and cardboard are among the easiest materials to recycle and reuse, as they can be recycled up to seven times. For this reason, they can be regarded as valuable assets. Waste from industrial processes and separately collected municipal waste can be injected back into the economy as raw material. In turn, paper made from recycled material can be reused and fed back into the production cycle without affecting the quality of the final product. This could bring about significant environmental benefits and savings in the use of virgin fibre and water, as well as a reduction in $\mathrm{CO} 2$ emissions. In 2017, it was estimated that following recycling of 3.9 million tons of cellulosic packaging, over 2.6 million tons of equivalent $\mathrm{CO} 2$ emissions were avoided (Danieli, 2019).

Traditionally, paper for recycling represents the first source of fibres for the manufacture of paper in Italy with a $7.8 \%$ circularity rate, second only to the Netherlands (26.7\%), while the European average rate stands at $17.8 \%$. 


\section{Conclusion and Emerging Issues}

Over the years, the Italian paper industry has seen great advances thanks to strategies aimed at improving its production technologies and related processes and optimizing the use of recycled fibres made available through separate waste collection and sorting activities.

This calls for the need to implement policies targeted at enhancing and fostering the recovery of "waste from recycled paper" and "cellulose processing waste" in order to consolidate circular economy policies. In this respect, strategic planning could entail building next-generation paper mills capable of "processing" paper for recycling. This would cause an increase in the amount of finished goods with higher added value while improving export competitiveness. Likewise, self-sufficient paper mills in terms of energy and waste management processes, devoted to the "processing" of cellulose, could also play a pivotal role.

This calls, on the one hand, for entrepreneurs and business executives to implement process innovation through the design of electromechanical systems and innovative industrial machinery with high energy efficiency, with a view to achieve a selfsufficient plant for the production of energy and gas. On the other hand, this also calls for public sector managers and heads of scientific research centers to be willing to engage in dialogue with entrepreneurs as regards research, development and experimentation with eco-friendly advanced business models while paving the way towards a circular economy.

\section{Bibliography}

Brondoni, S. M. (2020). Competitive Circular Economy Management. The Mitsubishi Corporation Case. Symphonya. Emerging Issues in Management (symphonya.unicusano.it), (1), 10-25.

http://dx.doi.org/10.4468/2020.1.02brondoni

Brondoni, S. M., \& Zaninotto, E. (2018). Overture de 'The $4^{\text {th }}$ Industrial Revolution. Business Model Innovation \& Global Competition', Symphonya. Emerging Issues in Management (symphonya.unimib.it), (2), 1-7.

http://dx.doi.org/10.4468/2018.2.01ouverture

Brondoni, S. M. (2014). Global Capitalism and Sustainable Growth. From Global Products to Network Globalisation. Symphonya. Emerging Issues in Management (symphonya.unimib.it), (1), 10-31.

http://dx.doi.org/10.4468/2014.1.02brondoni

Cantoni, F., Graziano, P., Maiocchi, F., \& Rizzi, P. (2019). A Territorial and Organizational Approach to Resilience, in Symphonya. Emerging Issues in Management (symphonya.unicusano.it), (2), 109-118.

http://dx.doi.org/10.4468/2019.2.10cantoni.graziano.maiocchi.rizzi

Comieco (2020). Comieco for Sustainable Development (in Italian). Rome.

European Commission (2014). Towards a Circular Economy: A Zero Waste Policy for Europe. Brussels: European Commission.

European Commission (2017). Report from the Commission to the European Parliament, the Council, the European Economic and Social Committee and the Committee of the regions. The Role of Wasteto-Energy in the Circular Economy, Brussels: European Commission.

European Commission (2018). Circular Economy Package. Brussels: European Commission.

European Commission (2019). Communication from the Commission to the European Parliament, the Council, the European Economic and Social Committee and the Committee of the Regions, The European Green Deal, Brussels, COM/2019/640. 
Fitch-Roy, O., Bensonb, D., \& Monciardini, D. (2020). Going Around in Circles? Conceptual Recycling, Patching and Policy Layering in the EU Circular Economy Package. Environmental Politics, 29(6), 983-1003.

http://dx.doi.org/10.1080/09644016.2019.1673996

Geissdoerfer, M., Savaget, P., Bocken, N. M. P., \& Hultink, E. J. (2017). The Circular Economy - A New Sustainability Paradigm? Journal of Cleaner Production, 143, 757-768.

http://dx.doi:10.1016/j.jclepro.2016.12.048

Ghisellini, P., Cialani, C., \& Ulgiati, S. (2016). A Review on Circular Economy: The Expected Transition to a Balanced Interplay of Environmental and Economic Systems. Journal of Cleaner Production, 114, 11-32.

http://dx.doi:10.1016/j. jclepro.2015.09.007

Korhonen, J., Honkasalo, A., \& Seppälä, J. (2018), Circular Economy: The Concept and Its Limitations. Ecological Economics, 143, 37-46.

http://dx.doi:10.1016/j. ecolecon.2017.06.041

Latini, M. (2019). Network, Consumer Co-Operatives and Sustainability. Symphonya. Emerging Issues in Management (symphonya.unicusano.it), (2), 30-37.

http://dx.doi.org/10.4468/2019.2.04latini

Lombardi, D. R., \& Laybourn, P. (2012). Redefining Industrial Symbiosis: Crossing AcademicPractitioner Boundaries. Journal of Industrial Ecology, 16 (1), 28-37.

http://dx.doi:10.1111/j.1530-9290.2011.00444.x

Ouadia, M., Brammera, J. G., Kayb, M., \& Hornunga, A. (2013). Fixed Bed Downdraft Gasification of Paper Industry Wastes. Applied Energy, 103, 692-699.

http://dx.doi.org/10.1016/j.apenergy.2012.10.038

Penco, L., Profumo, G., \& Tutore, I. (2019). Mission Statements and the Sustainability Communication. Symphonya. Emerging Issues in Management (symphonya.unicusano.it), (2), 95-108.

http://dx.doi.org/10.4468/2019.2.09penco.profumo.tutore

Rizzi, P. (2018). Hybrid Innovation in Global Business Management, in Brondoni, S. (ed.), Competitive Business Management. A Global Perspective, Routledge Abingdon, Oxon, Giappichelli Torino, 93-106.

Rizzi, P., Graziano P., \& Dallara A. (2015). The Regional Competitiveness: An Alternative Approach. Rivista Internazionale di Scienze Sociali, (3), 307-336.

Rizzi, P., Graziano, P., \& Dallara, A. (2018). A Capacity Approach to Territorial Resilience: the Case of European Regions. The Annals of Regional Science, 60, 285-328.

http://dx.doi.org/10.1007/s00168-017-0854-1

Salvioni, D. M., \& Almici, A. (2020). Circular Economy and Stakeholder Engagement Strategy. Symphonya. Emerging Issues in Management (symphonya.unicusano.it), (1), 26-44.

http://dx.doi.org/10.4468/2020.1.03salvioni.almici

Toczyłowska-Mamińska, R. (2017). Limits and Perspectives of Pulp and Paper Industry Wastewater Treatment - A Review. Renewable and Sustainable Energy Reviews, 78, 764-772.

http://dx.doi.org/10.1016/j.rser.2017.05.021

Trento, S., Bannò, M., \& D'Allura, G. M. (2018). The Impact of the $4^{\text {th }}$ Industrial Devolution on the Hightech Industry. Symphonya. Emerging Issues in Management (symphonya.unimib.it), (2), 145-157.

http://dx.doi.org/10.4468/2018.2.11trento.banno.dallura

United Nations (2015). Transforming our World: The 2030 Agenda for Sustainable Development. Washington. 